\title{
A CRITICAL REVIEW OF THE DYNAMICS OF GOVERNMENT DEBT SERVICING IN ZIMBABWE
}

\author{
Talknice Saungweme PhD student \\ Department of Economics \\ University of South Africa \\ Email: talknice2009@gmail.com \\ Professor Nicholas M. Odhiambo \\ Department of Economics \\ University of South Africa \\ Email: odhianm@unisa.ac.za /nmbaya99@yahoo.com
}

(Received: March 2018; Accepted: June 2018)

\begin{abstract}
This paper provides a conceptual analysis of government debt servicing in Zimbabwe from 1980 to 2015. The mounting debt burden arising largely from nonconcessionary foreign loans since the $1980 \mathrm{~s}$, and the economic hardships that characterise the country beginning the late 1990s, caused dreadful public debt servicing challenges. Thus, the paper discusses the public debt service reforms and policies; trends; and problems in Zimbabwe over the review period. In the paper, it was identified that between 1983 and 1997, the government's debt servicing costs were growing exponentially, resulting in liquidity challenges. However, between 1998 and 2015, the country had plunged into public debt service overhang, with public debt servicing liabilities exceeding the country's foreign exchange earnings. Notwithstanding the various public debt servicing reforms to boost domestic revenues, Zimbabwe, as many other developing countries, still faces a number of debt servicing problems. Among others, these include: high government debt, low industrial and export competitiveness, narrow revenue base and subdued investor confidence. The paper recommends the government of Zimbabwe to undertake the following measures, among others, aimed at either boosting or expanding the revenue base: (i) improving tax enforcements; (ii) mobilising the informal sector; and (iii) expanding the productive capacity of public entities.
\end{abstract}

Key words: Public debt servicing, economic growth, Zimbabwe

JEL Codes: H52, H62, H63, O11

\section{Introduction}

In theoretical literature, the link between government debt servicing and economic growth largely supports a negative relationship, predominantly in a neoclassical setting. Government debt servicing costs are believed to have the effect of creating economic and financial uncertainties, which ultimately hampers gross capital formation through discouraging potential foreign investments and prompting 
capital flight (Clements et al., 2005, pp. 34; Baneth, 2003, pp. 5; Moss and Chiang, 2003, pp. 3-4; \& Ajayi and Khan, 2000, pp.10). According to Krugman (1988), government debt becomes an issue of concern when the country's accumulated debt outstrips the ability to repay it. Krugman (1988) further asserts that, economic uncertainty brought about by rising government debt servicing obligations has compelled many world governments to adopt discretionary measures in order to finance their revenue-expenditure gaps.

While countries such as China, India, Colombia, Thailand and the Republic of Korea have escaped the debt servicing problems by adopting efficient borrowing policies and by implementing prudent investment policies, which expanded their export base; the situation is, however, different in most sub-Saharan African (SSA) countries, Zimbabwe included (International Monetary Fund "IMF", 2016, pp. 51). The government debts, mostly foreign, were rising exceptionally high in the SSA region since the early 1980s relative to the expansion in both industrial and export base - resulting in a cumulative regional public debt servicing cost in excess of US $\$ 10$ billion in 1995 (World Bank, 2003, pp. 145-153). Despite progressive foreign government debt repayment initiatives by most SSA countries, including Zimbabwe, public debt servicing ability remained constrained by numerous factors. These include: (i) high stocks of government debt; (ii) low industrial and export competitiveness; (iii) rising levels of capital flight; (iv) depressed investor confidence; and (v) severe liquidity constrains (IMF, 2016; United Nations, 1999). According to Ajayi (1997, pp. 5), the rising government debt servicing obligations in SSA in the 1980s and 1990s perpetuated the outflow of both financial and nonfinancial resources in the region.

The evolution of public debt stocks and public debt repayments in Zimbabwe dates back to the early 1980 s when the country generally adopted a development strategy that relied heavily on foreign financing (Mupunga \& Le Roux, 2014). The resultant burgeoning fiscal imbalances racked up government debt with the consequence of increasing domestic interest rates (Southern African Development Community "SADC", 2016). By 1990, Zimbabwe's cost of public debt servicing constituted a significant proportion of government revenue (SADC, 2016). In 1999, the inexorable cost of public debt servicing began to erode the capability of the state to effectively fund human developmental programs and public sector investments (African Development Bank "AfDB", 2005). A considerable amount of financial resources was diverted towards the payment of interest on both domestic and foreign public debt (AfDB, 2012a). Consequentially, the mounting cost of public debt servicing in Zimbabwe brought about stern structural revenue reforms, in the form of economic and financial restructuring. These revenue reforms included the introduction of new taxes, increases in existing tax rates as well as the introduction 
of interest and exchange rate controls - which possibly crowded out private sector investment. The combination of shrinking economic base and rising public debt servicing costs inevitably constrained the economic growth prospects of Zimbabwe over the period under review (AfDB, 2012b).

In light of this background, the objective of this study is to examine the evolution of government debt servicing in Zimbabwe from 1980 to 2015, focusing mainly on debt service structural reforms, trends, and problems. The outline of the paper is as follows: Section 2 reviews government debt service reforms in Zimbabwe; Section 3 discusses the debt servicing trends in Zimbabwe; Section 4 discusses the challenges associated with public debt servicing in Zimbabwe; and Section 5 provides the conclusion and recommendations.

\section{A review of public debt reforms in Zimbabwe}

During the late 1970s and early 1980s, Zimbabwe amassed huge foreign public debt, which it subsequently found problematic to repay in the late 1990s, prompting a series of debt servicing reforms (IMF, 2001). Coincidentally, in the early 1990s, the creditor community had started to embark on numerous massive debt reforms, such as debt relief initiatives and debt restructuring programmes (Das et al., 2012, pp. 30-31). The public debt reforms by the international community followed the realisation that most developing countries were failing to meet their external financial obligations. Unfortunately, Zimbabwe was not among the recipients of any of the debt relief initiatives by the Bretton Woods Institutions, the Paris Club and other creditors. Therefore, Zimbabwe's public debt repayment challenges during the review period varied from acute balance of payment difficulties to economic and financial problems (IMF, 2001).

According to the World Gold Council (1999, pp. 49), Zimbabwe is among the highly indebted countries in the world and is among the SSA countries which were not considered in the highly indebted poor countries (HIPCs) and the Multilateral Debt Relief (MDR) initiatives. Resultantly, the debt levels and servicing position of the country worsened in the 1990s. The servicing of foreign government debt after 1995 was absorbing huge budgetary and foreign exchange resources - more than 20 percent of exports of goods and services receipts - leaving little money to spend on health, education and social service delivery (Government of Zimbabwe "GoZ", 2013). During the review period, government debt servicing costs in Zimbabwe were rising sharply due to the continuous accumulation of interest on foreign debt arrears (IMF, 2012a). Consequently, the country undertook a series of non-HIPC economic reforms with the intention of finding lasting solutions to the debt servicing crisis, and of seeking ways of unlocking fresh capital injections - so as to contribute meaningfully towards the accomplishment of sustainable economic

22 S sciendo Studia Universitatis "Vasile Goldis" Arad. Economics Series Vol 28 Issue 3/2018 ISSN: 1584-2339; (online) ISSN: 2285 - 3065

Web: publicatii.uvvg.ro/index.php/studiaeconomia.Pages $20-36$ 
growth and poverty reduction goals (Mumbengegwi, 2002). While domestic public debt servicing reforms centred mostly on fiscal and monetary policy adjustments, the foreign government debt servicing reforms, apart from actual principal and interest repayments, included (i) negotiations and application of new loan agreements with private banks and International Financial Institutions (IFIs); (ii) establishment of a new structured framework for re-engaging with the international community - so as to normalise relations and seek removal of economic and political sanctions; (iii) utilisation of donor grants, special drawing rights (SDRs) and new loans; (iv) introduction of new debt instruments; and (v) debt restructuring (IMF, 2017; Reserve Bank of Zimbabwe "RBZ", 2015; GoZ, 2009a).

From a historical stand point, the share of Zimbabwe's domestic public debt increased markedly in the last half of the 1990s. The cumulative domestic public debt stock reached a record high of Z\$2.2 trillion in August 2004 (RBZ, 2005). In an effort to ease domestic debt payments, the Zimbabwean government, between 1998 and 2008, began to aggressively control domestic interest rates and exchange rates (RBZ, 2016a). With incessant liquidity challenges, the government, in 1999, begun to stagger payments to its domestic and foreign creditors as well as freezing civil service employment and wages (Brett, 2005). Between 2002 and 2004, more than 60 percent of government revenue was channelled towards interest payments on domestic public debt, prompting the government to undertake domestic debt restructuring measures - mostly a diversion from short- to long-term domestic debt, and re-capitalisation of matured domestic debt (RBZ, 2004). By December 2004 , for instance, the government had an obligation of paying $Z \$ 1210.8$ billion of 182-day matured treasury bills, $\mathrm{Z} \$ 0.5$ billion of 365-day matured treasury bills, $\mathrm{Z} \$ 310$ billion of 2 years matured treasury bills and $\mathrm{Z} \$ 4.3$ billion of matured treasury bills (Ministry of Finance and Economic Development "MOFED”, 2005). The high domestic public debt service payments and associated liquidity challenges impelled the government to restructure its domestic debt, leading to a shift towards 91-day and 2-year treasury bills, which reached a share of 99.4 percent in January 2007, compared to 5 percent in 1990 (RBZ, 2008). Other new long-term domestic public debt instruments that were introduced by the government of Zimbabwe include the 3-year variable coupon insurance industry bond worth $\mathrm{Z} \$ 4.3$ trillion introduced in 2007 (RBZ, 2008). However, despite these reforms, domestic public debt service payments remained very high, reaching $Z \$ 5.9$ trillion, equivalent to 27.8 percent of total outstanding government domestic debt, in January 2008 (RBZ, 2008).

Legislatively, the government of Zimbabwe enacted the Reconstruction of State Indebted Insolvent Companies Act in 2004, with the principal intention of managing domestic public debt servicing commitments. The act provides for the 
reconstruction of state-indebted enterprises that are incapable to repay amounts made to them from public funds (Reconstruction of State Indebted Insolvent Companies Act, 2004, pp. 5). The thrust of the act was to curtail rising domestic public debt servicing burden, which was springing from loss-making public enterprises and other government guaranteed businesses.

Between 2009 and 2015, the Zimbabwean government also instigated numerous revenue reforms, which included the enforcement of the presumptive tax to the informal sector, and the introduction of a monthly payment system for the presumptive tax, instead of the previously used quarterly system (MOFED, 2015) These revenue rearrangements were intended to enhance the government's capacity to honour its domestic financial dues by expanding the state's revenue base. Other domestic public debt service reforms that were instituted by the government in the multicurrency era include: (i) putting a ceiling on total stock of arrears to domestic service providers, especially agricultural input suppliers, and on capital certificates; and (ii) putting a floor on protected social spending (GoZ, 2013).

Apart from domestic public debt service reforms, the government also embarked on a chain of foreign public debt service reforms since independence. However, the government's foreign debt service reforms between 2000 and 2008 were not so pronounced and only became sound during the era of the Government of National Unity (GNU) (SADC, 2016). Following the failure to honour its foreign debt arrears in 1999, the government sought sovereign debt restructuring from the Paris Club, the AfDB and the Bretton Woods Institutions (GoZ, 2010, pp.69). According to Das et al. (2012, pp. 16), sovereign foreign debt restructuring "is an exchange of outstanding government debt, such as bonds or loans, for new debt products or cash through a legal process". To spearhead the re-engagement negotiations with the creditor community, the government of Zimbabwe adopted the Zimbabwe Accelerated Arrears Clearance, Debt, and Development Strategy (ZAADDS) document. The ZAADDS policy was embraced to: (i) facilitate the restoration of economic relations with creditors, and ensure a financial re-engagement with the international community; and to (ii) recuperate investor confidence (GoZ, 2013, pp. 48). The ZAADDS also intended to set a framework for seeking (i) extension of contractual repayments period; (ii) rescheduling and restructuring of foreign public debts from the traditional lenders; and (iii) a reduction of interest rates on outstanding arrears and principal debts (RBZ, 2012).

In response to the country's requests through ZAADDS, the international creditor community, mostly, the Bretton Woods Institutions, the AfDB and the Paris Club, demanded that the government of Zimbabwe first addresses the following issues; (i) improves diamond revenue transparency, (ii) rationalise the civil servant wage bill, (iii) accelerate the restructuring process of the central bank to promote 
financial sector stability, among others (IMF, 2012b; GoZ, 2009b). Consequentially, between 2009 and end of 2010, the government of Zimbabwe enacted a series of economic recovery programmes, which included the ShortTerm Economic Recovery Programme I and II, and the Medium-Term Plan. More so, the government formulated the Zimbabwe Accelerated Reengagement Economic Programme (ZAREP) as a means of speeding up its commitment in finding lasting solutions to the foreign public debt service payment challenges. The implementation of the IMF-supported staff-monitored programme (SMP) and the clearance of the IMF arrears in October 2016 is testimony of the country's commitment to ZAREP (RBZ, 2016b; IMF, 2013). Nonetheless, despite undertaking the aforementioned reforms and the installation of a new government dispensation, the GNU, Zimbabwe's traditional creditors - the IMF and African Development Bank - reiterated that they would only make new loan disbursements to the country after existing debts have been cleared (Besada, 2011, pp. 209).

The other foreign public debt servicing approach undertaken by the government was the usage of SDRs, grants and new loans to clear accumulated foreign debt arrears. Using this approach, the government prioritised the clearance of arrears owed to the IMF, World Bank Group and the AfDB (GoZ, 2012). In 2015, the government used its special drawing rights holdings to pay off the US\$110 million arrears owed to the IMF (RBZ, 2016b). In 2014, the country passed a resolution to put a floor on payments to the Poverty Reduction and Growth Trust (GoZ, 2015). More so, the government signed for new loan facilities from the African ExportImport Bank (Afreximbank), to pay off the remaining debt arrears of US $\$ 585$ million and US\$16 million to AfDB and Africa Development Fund (ADF), respectively, by end of 2015 (GoZ, 2012). Additionally, the government used another loan facility from China to the tune of US\$1.1 billion to make part payments to the outstanding arrears to the World Bank Group, comprising of the International Bank for Reconstruction and Development (US\$896 million) and the International Development Association (US\$218 million) (RBZ, 2016a).

Furthermore, to accelerate the repayment of foreign public debts, the government of Zimbabwe in 2015 began to undertake some institutional reforms aimed at enhancing public debt consolidation and servicing. The government, through the financial and technical backing of the AfDB, is setting up a Debt Management Office, which will assume, among other responsibilities, the implementation of the country's arrears clearance and debt relief strategies (AfDB, 2012b).

Other foreign debt servicing restructurings included currency and financial reforms implemented between 2013 and 2016. These include the introduction of bond money and reintroduction of stern exchange controls. The introduction of bond money was part of the government's initiative to reduce externalisation of foreign 
currency and thus help in the rebuilding of foreign exchange reserves required for the payment of foreign debts and arrears (RBZ, 2017). During the same period, the central bank implemented stringent foreign exchange measures, such as the need to seek authorisation from the RBZ by individuals and corporates before making any foreign payment (RBZ, 2017). The government's thrust in undertaking the above financial reforms was to enhance the usage of domestically generated revenues in meeting foreign financial commitments.

Apart from structural and institutional debt servicing reforms, the country has, since 2009, stepped up measures to strengthen its debt management and servicing capabilities by undergoing fiscal and legal reforms. In 2013, the government stipulated in the Zimbabwe Agenda for Sustainable Socio-Economic Transformation policy document that it would, between 2013 and 2018, improve its debt management and servicing ability by undertaking regular debt sustainability analyses, and restrict itself to sustainable borrowing practises (GoZ, 2013, pp. 117). Among the recent legal debt management and servicing laws is the Public Debt Management Act of September 2015, which sought to provide a comprehensive guidance on issuance of debt and guarantees, as well as on public debt servicing and reporting (GoZ, 2016). This act, and all other servicing reforms described above, were among the government's adopted measures directed towards enhancing the country's commitment and capability in clearing foreign financial arrears during the period under review. In general, the thrust of the public debt servicing reforms was to improve the capacity of the state in honouring its foreign debt dues by boosting the country's revenue base.

\section{Government debt servicing trends in Zimbabwe}

Similar to many African countries, public debt servicing in Zimbabwe became a source of apprehension in the early 1980s due to a number of factors, which include: (i) rising nonconcessionary loans, (ii) increased maturity of inherited debt, (iii) soaring world interest rates, (iv) contracting revenue bases, and (v) low export competitiveness (IMF, 1998). Following the rise in global interest rates between 1981 and 1985, and the massive deterioration in the country's terms of trade in the late 1990s, aggregate public debt payments reached US $\$ 435.4$ million in 1983, and averaged US $\$ 402$ million for the period from 1983 to 1999 (World Bank, 2012). According to Jenkins and Knight (2002), the rising public debt servicing burden and the inability of the country to access concessionary loans on the foreign capital markets, affected the country's economic growth rates. Presently, Zimbabwe is in public debt service distress, as evidenced by perpetual revenue constraints, emanating from suppressed industrial performance and low export competitiveness (IMF, 2014, pp. 17-18). Zimbabwe's foreign public debt is in arrears by

26 S sciendo Studia Universitatis "Vasile Goldis" Arad. Economics Series Vol 28 Issue 3/2018 ISSN: 1584-2339; (online) ISSN: 2285 - 3065

Web: publicatii.uvvg.ro/index.php/studiaeconomia.Pages $20-36$ 
Saungweme, T., Odhiambo, N.M. (2018)

A critical review of the dynamics of government debt servicing in Zimbabwe

approximately 79 percent, a condition which prompted the government to undertake debt service reconciliation initiatives beginning 2003 (IMF, 2016b). Figure 1 presents the trends of selected government debt service sustainability indicators in Zimbabwe from 1980 to 2015.

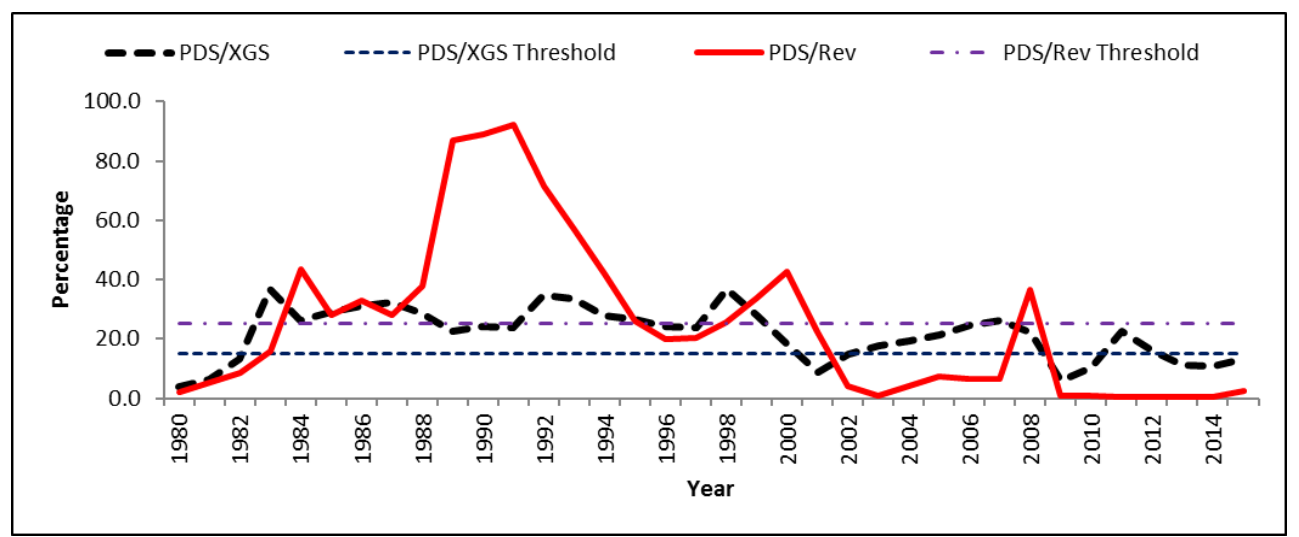

Figure 1: Government debt service trends in Zimbabwe (1980-2015)

Source: RBZ (2012); SADC Statistical Year Book 2016; World Development Indicators (2012)

$X G S=$ Exports of goods and services; PDS = Total public debt service; Rev = Government revenue

In Figure 1, from 1983 through to 1998, Zimbabwe was suffering from liquidity challenges as evidenced by public debt service-to-export of goods and services ratio and public debt service-to-government revenue ratios which were, on average, above the IMF/World Bank sustainability thresholds of 18 percent and 25 percent, respectively. Despite the increased debt servicing liabilities during this period, the government was still honouring both its domestic and foreign debt obligations. Contrariwise, the country, between 1998 and 2008, was incapacitated to make consistent service payments owing to the severe economic and financial problems that characterise the country during this period. As illustrated in Figure 1, the cumulative effect of the crises was a fall in public debt service, leading to the fall in the two ratios (SADC, 2016). In particular, in 2001, the Zimbabwe's Minister of Finance alluded that "we are committed to fulfilling these obligations, but it's clear that our economy is in no state to generate sufficient funds to clear the arrears..." (Bond, 2005, pp. 615). After 2009, the government started to make paltry debt payments, mainly towards arrears, using finances from the drawing down of special drawing rights or from new loans. Overall, although debt service ratios have remained relatively low since 2000 as shown in Figure 1, the country has been unable to service its foreign public debts, resulting in: (i) the accumulation of 
arrears; and (ii) in a recourse towards debt rescheduling under the Paris Club arrangements (GoZ, 2009b, pp. 69-70).

Between 1983 and 1998, 28.8 percent of Zimbabwe's exports receipts, on average, were spent on public debt repayments, mostly foreign debt, - an indication of acute resource outflow (World Bank, 2012). More so, an average of 44.1 percent of the government's revenue was channelled towards debt and interest payments, a condition which could have contributed to a stern reduction in education, health and other social service expenditures in the 1990s (United Nations Development Programme, 2012, pp. 14). Zimbabwe stopped servicing its foreign public debts in 1999 perceiving them as being too costly in terms of the country's economic and social objectives (Gono, 2008, pp. 46). Thus, the servicing constraints during the period under review were generally a result of the poor performance of the economy and of the government's limited borrowing options.

The high government debt service-to-revenue ratio in Figure 1, during the first two decades may also have perpetuated budget disequilibrium and triggered the economic and financial reforms described in Section 2 (SADC, 2016). Thus, the high public debt service burden prior to 1999 might have hindered the country's economic growth by depriving the country of foreign exchange needed for public sector investment and for the provision of critical industrial enablers. Furthermore, the soaring in world interest rates and drastic depreciation in the value of the local currency in the 1980s and 1990s are among the other factors that might have forced Zimbabwe to plunge into foreign public debt overhang and debt service crisis, a condition which characterise the country even today (World Bank, 2015). The excessive devaluation of the Zimbabwean dollar, stern foreign exchange shortages, and high nominal exchange rates (from incessant runaway inflation), between 2004 and 2008, are among the factors which contributed to Zimbabwe's public debt service overhang (African Forum and Network on Debt and Development "AFRODAD", 2012).

According to the IMF (2014, pp. 11), the failure by the public sector to honour its foreign financial obligations between 1998 and 2008 and the implementation of the indigenisation policy had a compounding chilling effect on foreign investment. Additionally, government initiatives to raise foreign exchange to service its debt during this period led to reforms in financial regulatory frameworks, including the imposition of stern foreign exchange restrictions (IMF, 2014, pp. 54). Also, under the inflationary environment, which stretched from 2003 to 2008, the government revenues (mainly seigniorage revenue) were much higher than expenditures, permitting the government to redeem its entire domestic debt by February 2009 (MOFED, 2009). However, in the multicurrency era, the issuance of treasury bills worth US $\$ 4417$ million by 2014 , with a total of US\$1102 million having matured

28 S sciendo Studia Universitatis "Vasile Goldis" Arad. Economics Series Vol 28 Issue 3/2018 ISSN: 1584-2339; (online) ISSN: 2285 - 3065

Web: publicatii.uvvg.ro/index.php/studiaeconomia.Pages $20-36$ 
and liquidated, describes the upward turn in the government debt servicing indicators in Figure 1 (MOFED, 2017). Beginning 2014, the government had been making regular payments to domestic government debt holders and to the International Financial Institutions. For instance, the government paid monthly instalments of US\$150,000 to the IMF's Poverty Reduction and Growth Trust, in addition to the quarterly payments of US\$900,000 and US\$500,000 to the World Bank and to the AfDB, respectively (RBZ, 2015).

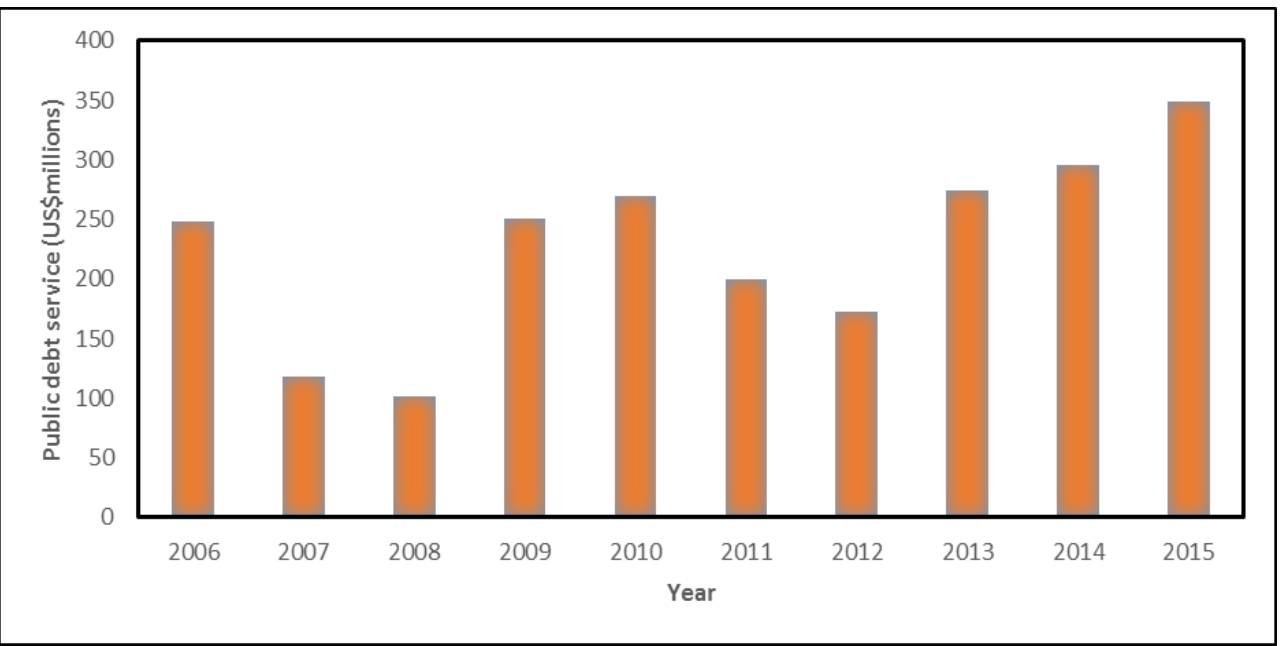

Figure 2: Public and publicly guaranteed foreign debt repayments in Zimbabwe (2005-2015) Source: SADC Statistical Year Book (2016)

In contrast to the period prior to 2009 where the government would service its domestic debt through seigniorage revenue, under the dollarisation period (post2009), the government is recommended to expand its revenue base and improve the country's business environment in order for it to meet its domestic and foreign debt liabilities, sustainably. The government of Zimbabwe can directly increase its revenues by improving tax enforcements, mobilising the informal sector, expanding the productive capacities of public entities, attracting foreign direct investment (through revising the current indigenisation policy - or even suspending it; and ensuring security of private property by honouring property right laws), and also implementing policies that enhance economic activity, income and wealth generation. This will be in addition to radical reductions in recurrent public consumption expenditures. This means that the Zimbabwean government will have to continue with the public debt service restructuring programs and also continuously work on actively normalising its relations with the international 
community so as to find lasting solutions to its debt servicing crisis, and hence promote sustainable economic growth. Figure 2 provides a summary of public and publicly guaranteed foreign debt payments in Zimbabwe from 2005 to 2015.

Figure 2 reveals that a total of US\$248 million was paid in 2006, and this was mainly to the IMF and the World Bank (SADC, 2016). With increased economic crisis between 2006 and 2009, the country's capacity to pay its creditors subdued as evidenced by the fall in service payments in Figure 2. Visible also in Figure 2 is a renewed focus towards foreign debt repayment by the government in 2009 in an effort to pay off arrears, with the hope of opening up new lines of credit and of enhancing the country's credit rating.

\section{Problems of government debt servicing in Zimbabwe}

Zimbabwe, like many other African countries except South Africa, has a very high proportion of foreign government debt than domestic debt (World Bank, 2010). Henceforth, debt servicing challenges in Zimbabwe are mainly to do with the settlement of foreign currency denominated government debt, both arrears and principal amounts (World Bank, 2016, pp. 3). According to the International Monetary Fund (2017, pp. 3), the exponential rise in public indebtedness in Zimbabwe since the 1980s has been an obstacle to national development, since a considerable amount of financial resources were being committed towards debt servicing. The huge government debt servicing burden crowded out both public and private sector investments, thereby aggravating liquidity shortages, and hence intensified debt service distress (GoZ 2009a, pp. 53; IMF, 2017, pp. 3, 11). Therefore, government debt servicing challenges in Zimbabwe are a result of, among other reasons: (i) liquidity constraints due to poor economic performance; (ii) lack of proper public sector financial management principles; (iii) improper composition and structure of the public debt (which is mainly short term and nonconcessional); (iv) low investor confidence; (v) low industrial and export competitiveness; and (vi) poor economic relations with the international donor community (Danha et al., 2015; IMF, 2013; 2015).

Government debt repayment challenges for the local currency denominated debt have generally been concerted around poor economic performance, which had its origin in the late 1990s (AFRODAD, 2011). The perpetual economic crises, lack of foreign financing, adverse political environments and international economic sanctions that characterised the country in the second decade of political independence accelerated the rate of economic contraction, leading to the narrowing of the government's revenue base (GoZ, 2013). With increased maturity of domestic debt in 1999, the servicing burden skyrocketed, thus worsening the government's capacity to repay its debts (IMF, 2013). Both public and private

30 S sciendo Studia Universitatis "Vasile Goldis" Arad. Economics Series Vol 28 Issue 3/2018 ISSN: 1584-2339; (online) ISSN: 2285 - 3065

Web: publicatii.uvvg.ro/index.php/studiaeconomia.Pages $20-36$ 
sector gross savings and gross investment in productive activities have remained subdued over the review period, hence exacerbating the narrowing of the country's tax revenue base (Nyarota et al., 2015).

Active government participation in capital and money markets in the mid-1990s caused domestic nominal interest rates to rise, leading to the steep upsurge in the cost of servicing maturing domestic public debt - with the consequence of defaulting in 1999 (Sibanda and Dubihlela, 2013). The constant recapitalisation, restructuring and rescheduling of domestic debt by the government due to liquidity challenges eroded the confidence of savers and investors, both domestic and foreign, and perpetuated capital outflows into lucrative foreign capital markets (World Bank, 2016). Thus, in a way, the severe capital outflows that rocked the country between 1998 and 2008 were in part compounded by the government's defaults on domestic debt payments. In particular, economic agents interpreted the debt payment defaults as eminent future rise in tax obligations and also as impending depreciation of the local currency, resulting in the erosion of investor confidence. Thus, a combination of rising nominal interests on domestic debt, narrowing tax revenue base and adverse developments in commodity export prices contributed to the increased problems of domestic public debt servicing in Zimbabwe in the 1990s (RBZ, 2004).

According to the 2010 and 2011 budget statements, the lack of public sector financial transparency also contributed to domestic public debt servicing problems in Zimbabwe (MOFED, 2011, 2012). The Ministry of Finance and Economic Development (2011) reported in the 2011 budget statement that it was not receiving sound revenue flows from the auctioning of diamonds. In consequence, there was a swelling up in fiscal deficits, worsening the debt repayment ability of the government.

Foreign public debt servicing challenges in Zimbabwe originated mostly from the magnitude, composition and structure of the government foreign debt. This was in addition to negative economic developments in the country and abroad (RBZ, 2014). The foreign government debt in Zimbabwe was primarily non-concessional (IMF, 2013). As a result of this debt constitution, the government, in 1999, faced liquidity challenges as more than 80 percent of its foreign debt contracted in the 1980s had matured, resulting in severe debt service defaults (RBZ, 2003). Liquidity challenges were worsened by economic crises and increased financial sector vulnerabilities that rocked the country in 1998. The fall in terms of trade of mineral and agricultural exports further intensified the problem of foreign debt servicing in Zimbabwe (World Bank, 2010). According to Dumitru et al. (2015, pp. 23), the deterioration of international financial conditions in 2007 worsened liquidity 
conditions on the internal market of most developing countries, thus negatively impacting the refinancing of public debts.

Foreign public debt servicing problems were also exacerbated by the imposition of financial and economic sanctions on the country in 1999 and 2000 by both the western economies and most IFIs (GoZ, 2013, PP. 8, 11-12). These sanctions added to the existing foreign debt servicing challenges in Zimbabwe in numerous ways - (i) led to the drying up of grants, which the country used to receive from developmental partners, especially from multilateral financial institutions; (ii) fostered the cancellation of budget and balance of payment financial support from the Bretton Woods Institutions, thus constraining the revenue base of the state; (iii) led to the loss of most lucrative commodity export markets, especially that of beef to Europe; (iv) led to the disappearance of cheap lines of offshore finances; and (v) intensified capital flight (Besada, 2011; World Bank, 2016, pp. 3-9). The cumulative outcome of these adverse developments was a general contraction of the Zimbabwean economy, leading to the excessive fiscal imbalances and unabated contraction of new non-concessionary foreign public debt - and ultimately disproportionate debt servicing burden (GoZ, 2009b).

The inability to pay foreign public debt also stemmed from the non-extension of foreign public debt relief initiatives to Zimbabwe by IFIs, the Paris Club and other private banks in developed countries. Consequentially, the IMF (2017, pp. 66) alluded that the Zimbabwe's indebtedness continued to outgrow its capacity to pay, mainly due to incessant amassing of interest arrears, and so, there was little chance that the country would emerge from this debt servicing problem in the near future. Additionally, the ejection of the country from most world capital markets made the country more susceptible to fiscal shocks since its domestic capital markets are still underdeveloped and undiversified.

\section{Conclusion and recommendations}

This paper has reflected on the dynamics of government debt servicing in Zimbabwe from 1980 to 2015 . The study was motivated by the mounting public debt servicing burden in most developing countries in the 1980s and 1990s, including Zimbabwe, where the rate of public debt service payments have been twice the growth in export earnings and of gross domestic product. Thus, the paper highlighted the public debt servicing reforms and policies, trends and challenges in Zimbabwe during the period under review. The debt servicing reforms and policies varied from establishment of new structured frameworks, aimed at spearheading the re-engagement process with the creditor community, to new public debt servicing methods, such as the usage of special drawing rights and contraction of new loans to pay off debt arrears.

32 Sciendo Studia Universitatis "Vasile Goldis" Arad. Economics Series Vol 28 Issue 3/2018 ISSN: 1584-2339; (online) ISSN: 2285 - 3065

Web: publicatii.uvvg.ro/index.php/studiaeconomia.Pages $20-36$ 
In the discussions, three debt service payment periods were identified. These are: (i) 1983 to 1997; (ii) 1998 to 2008; and (iii) 2009 to 2009. During the period from 1983 to 1997 , debt servicing costs were mounting, although the country was still making constant payments. In the period from 1998 to 2008, economic challenges in the country led to government debt servicing challenges. Although public debt servicing indicators fell to below International Monetary Fund and the World Bank sustainability thresholds during this period, the outcome was not a result of a reduction in the magnitude of the arrears but of the capacity to pay. Public debt service payments during this period went down and the country's cases of servicing defaults increased, leading to accumulation of public debt arrears.

Following the need to open up new lines of international finance, the country, from 2009 to 2015, began to make some foreign debt payments, starting with the clearance of arrears to the International Monetary Fund, the World Bank and the African Development Bank. Overall, it was revealed in the paper that the currency composition of the government debt, that is, the high dependence on foreign capital, contributed immensely to the debt servicing problems in Zimbabwe. Other identified government debt servicing challenges in Zimbabwe, like in any other developing countries included: (i) high government debt; (ii) low industrial and export competitiveness; (iii) narrow revenue base; and (iv) subdued investor confidence. The paper recommends the government of Zimbabwe to undertake the following measures aimed at either boosting or expanding the revenue base, among others: (i) improving tax enforcements; (ii) mobilising the informal sector; (iii) expanding the productive capacities of public entities; (iv) revising the current indigenisation policy - or even suspending it and ensuring security of private property by honouring property right laws so as to attract foreign direct investment; and (v) implementing policies that enhance economic activity, income and wealth generation. To minimise liquidity challenges arising from debt servicing costs, the study also recommends the government to operate highly adaptable financial instruments and to build or promote the establishment of efficient financial infrastructure in the economy.

\section{References}

1. African Development Bank. (2005). African Economic Outlook. African Development Bank. Addis Abba, Ethiopia.

2. African Development Bank. (2012a). African Statistical Year Book. African Development Bank. Addis Abba, Ethiopia.

3. African Development Bank. (2012b). Zimbabwe: Country profile. African Development Bank. Addis Abba, Ethiopia.

4. African Forum and Network on Debt and Development. (2011-2012). Country Debt Profiles: Zimbabwe. Harare: AFRODAD. 
Saungweme, T., Odhiambo, N.M. (2018)

A critical review of the dynamics of government debt servicing in Zimbabwe

5. Ajayi, S.I. (1997). Analysis of external debt and capital flight in the severely indebted low-income countries in sub-Saharan Africa. International Monetary Fund. WP/97/68.

6. Ajayi, S.I., \& Khan, M.S. (2000). External debt and capital flight in sub-Saharan Africa. Washington, DC: International Monetary Fund. Economic issues.

7. Besada, H. (2011). Zimbabwe: Picking up the pieces. Palgrave Macmillan, United States of America.

8. Baneth, J. (2003). Some determinants of debt service sustainability in low-income aiddependent countries. Washington, DC: The World Bank; 1-59.

9. Bond, P. (2005). Zimbabwe's hide and seek with the IMF: Imperialism, nationalism and the South African proxy. Review of African Political Economy, 32(106): 609-619. Retrieved from: http://www.jstor.org/stable/20059112.

10. Brett, E. (2005). From corporatism to liberalisation in Zimbabwe: Economic Policy Regimes and Political Crisis (1980-1997). Working Paper No.58. London: Development Research Centre and LSE.

11. Clements, B., Bhattacharya, R., \& Nguyen, T. (2005). Can debt relief boost growth in poor countries? Washington, DC: International Monetary Fund. Economic Issues Number 34.

12. Danha, D., Takaindisa, J., Mlotshwa, L., \& Simleit, C. (2015). Zimbabwe Equity Strategy 2015: At Cross Roads. Harare: IH Securities.

13. Das, U., Papaioannou, M., \& Trebesch, C. (2012). Sovereign debt restructurings 19502010: Literature survey, data, and stylized facts. International Monetary Fund Working Paper No. 12/203.

14. Dumitru, A.L., Cristina, V., \& Petre, B. (2015). Governmental Liquidities Management 2008-2010. Studia Universitatis - Vasile Goldis Arad. Economics Series, 25(2): 115123.

15. Gono, G. (2008). Zimbabwe's Casino Economy. Harare: Zimbabwe Publishing House.

16. Government of Zimbabwe. (2009a). Short Term Emergency Recovery Programme. Harare: Printflow.

17. Government of Zimbabwe. (2009b). Medium Term Plan (MTP), 2010-2015. Harare: Republic of Zimbabwe.

18. Government of Zimbabwe. (2012). Zimbabwe Accelerated Arrears Clearance, Debt, and Development Strategy (ZAADDS). Reserve Bank of Zimbabwe.

19. Government of Zimbabwe. (2013). Zimbabwe Agenda for Sustainable SocioEconomic Transformation (ZIMASSET), October 2013-2018, Government of Zimbabwe.

20. Government of Zimbabwe. (2016). Public Debt Management ACT [CHAPTER 22:21]. Number. 4 of 2015. Harare: Printflow.

21. International Monetary Fund. Zimbabwe: Article IV Consultation, Staff Reports. Various years. Washington DC: International Monetary Fund.

22. International Monetary Fund. (1998). External Histories of Ten Low-Income Developing Countries: Lessons from Their Experiences. IMF Working Paper, WP/98/72. Washington DC: International Monetary Fund.

$34 \quad S$ sciendo Studia Universitatis "Vasile Goldis" Arad. Economics Series Vol 28 Issue 3/2018 ISSN: 1584-2339; (online) ISSN: 2285 - 3065

Web: publicatii.uvvg.ro/index.php/studiaeconomia.Pages $20-36$ 
23. International Monetary Fund. (2001). Zimbabwe: 2000 Article IV Consultation, Staff Report; Staff Supplement. Country Report No. 01/2001. Washington DC: International Monetary Fund.

24. International Monetary Fund. (2012a). Zimbabwe Macroeconomic Framework 20132019 and Debt Sustainability Analysis. Washington DC: International Monetary Fund.

25. International Monetary Fund. (2012b). Zimbabwe 2012 Article IV Consultation, IMF Country Report No. 12/279. Washington DC: International Monetary Fund.

26. International Monetary Fund. (2013). Zimbabwe 2013 Article IV Consultation: Staff Report; Press Release; and Statement by the Executive Director for Zimbabwe. Washington DC: International Monetary Fund.

27. International Monetary Fund. (2014). Zimbabwe 2014 Article IV Consultation: Staff Report; Press Release; and Statement by the Executive Director for Zimbabwe. Washington DC: International Monetary Fund.

28. International Monetary Fund. (2016a). Regional Economic Outlook. Sub-Saharan Africa: Time for a Policy Reset. International Monetary Fund.

29. International Monetary Fund. (2016b). Zimbabwe 2016 Article IV Consultation: Staff Report; Press Release; and Statement by the Executive Director for Zimbabwe. Washington DC: International Monetary Fund.

30. International Monetary Fund. (2017). Zimbabwe 2017 Article IV Consultation: Press Release; Staff Report and Statement by the Executive Director for Zimbabwe. IMF Country Report No. 17/196. Washington DC: International Monetary Fund.

31. Jenkins, C., \& Knight, J. (2002). The Economic Decline of Zimbabwe: Neither Growth nor Equity. London: Palgrave.

32. Krugman, P. (1988). Financing vs. forgiving a debt overhang. Journal of Development Economics, 29(2): 407-437.

33. Ministry of Finance and Economic Development. (2005). 2005 National Budget Statement. Ministry of Finance and Economic Development.

34. Ministry of Finance and Economic Development. (2009). 2009 National Budget Statement. Ministry of Finance and Economic Development.

35. Ministry of Finance and Economic Development. (2014). Treasury State of the Economy Report, 2014. Harare: Ministry of Finance and Economic Development.

36. Ministry of Finance and Economic Development. (2014). 2015 National Budget Statement. Ministry of Finance and Economic Development.

37. Ministry of Finance and Economic Development. (2017). Ministerial Statement in the National Assembly, Tuesday $11^{\text {th }}$ April 2017. Harare: Government of Zimbabwe.

38. Moss, T.J., \& Chiang, H.S. (2003). The other costs of high debt in poor countries: Growth, policy dynamics, and institutions. Issue paper on debt sustainability No.3. Centre for Global Development. Washington DC: 1-16.

39. Mupunga, N., \& Le Roux, P. (2014). Analysing the theoretical and empirical foundations of public debt dynamics in Zimbabwe. Economic Research Southern Africa (ERSA): 1-20.

40. Mumbengegwi, C. (2002). Macroeconomic and Structural Adjustment Policies in Zimbabwe. London: Macmillan, Palgrave. 
41. Nyarota, S., Kavila, W., Mupunga, N., \& Ngundu, T. (2015). An empirical assessment of binding constraints to Zimbabwe's growth dynamics. Reserve Bank of Zimbabwe Working paper series No.2: 1-38.

42. Reconstruction of State-Indebted Insolvent Companies Act [Chapter 24:27]: Act 27/2004. Government of Zimbabwe. Government printers.

43. Reserve Bank of Zimbabwe. (2003). Maiden Monetary Policy Statement. Harare: Fidelity Printers.

44. Reserve Bank of Zimbabwe. (2004-2014). Annual Reports. Harare: Fidelity Printers.

45. Reserve Bank of Zimbabwe. (2015). Weekly Economic Report. (Various editions) Harare: Fidelity Printers.

46. Reserve Bank of Zimbabwe. (2016a). History of Exchange Controls in Zimbabwe. Harare: Reserve Bank of Zimbabwe. Retrieved from: http://www.rbz.co.zw/reservebank-of-zimbabwe-exchange-control.html.

47. Reserve Bank of Zimbabwe. (2016b). Annual Report. Harare: Fidelity Printers.

48. Reserve Bank of Zimbabwe. (2017). Weekly Economic Review. Harare: Fidelity Printers.

49. Sibanda, D., \& Dubihlela, J. (2013). Factors that impede viable bond market development in one hyperinflationary economy. Review of Business and Finance Studies; 4(1): 107-118.

50. Southern African Development Community (SADC). (2016). SADC Statistical Yearbook 2015. SADC Secretariat, Gaborone, Botswana.

51. United Nations. (1999). Finding solutions to the debt problems in developing countries. Report of the Executive Committee on Economic and Social Affairs of the United Nations. CEPAL, Santiago, Chile, July 1999.

52. United Nations Development Programme. (2012). Zimbabwe Brown Bag Dialogue Series. The Debt Issue. Issue Number 3. Harare: United Nations Development Programme. Retrieved from: http://www.zw.undp.org/content/dam/zimbabwe/docs/Poverty\%20Reduction/UNDP_Z W_PR_BBag_The\%20Debt\%20Issue.pdf.

53. World Bank. (2003). Global Development Finance: Analysis and Summary Tables. Washington DC.

54. World Bank. (2010). World Development Indicators. Washington DC.

55. World Bank. (2012). World Development Indicators. Washington DC.

56. World Bank. (2016). Zimbabwe Economic Update: Changing Growth Patterns: Improving Health Outcomes. Issue 1. Washington DC.

57. World Gold Council. (1999). A Glittering Future: Gold Mining's Importance to SubSaharan Africa and Heavily Indebted Poor Countries. Public Policy Centre of the World Gold Council. 